\title{
A Brief Analysis of Tiger Totem Worship of Yi Nationality from the Perspective of Symbolism
}

\author{
Dirierzhe \\ College of Urban Planning and Architecture, Southwest Minzu University, Chengdu, China \\ Email: 853137573@qq.com
}

How to cite this paper: Dirierzhe (2021) A Brief Analysis of Tiger Totem Worship of Yi Nationality from the Perspective of Symbolism. Open Access Library Journal, 8: e7813.

https://doi.org/10.4236/oalib.1107813

Received: July 31, 2021

Accepted: August 22, 2021

Published: August 25, 2021

Copyright (c) 2021 by author(s) and Open Access Library Inc.

This work is licensed under the Creative Commons Attribution International License (CC BY 4.0).

http://creativecommons.org/licenses/by/4.0/

\begin{abstract}
The totem worship is a phenomenon in the development of human culture, is the key element of national reproduction and development, occupies an important position in the national culture Explore the tiger totem which contains the meaning of national spirit and culture as well as the nation, and is along the history to understand and to revisit the Yi people life and spirit of the era of cultural beliefs important way. At the same time, through the analysis and comparison of the origin and different values and meanings of other totems, we can have a deeper understanding of our nation's totem culture, which is conducive to enhancing national identity and sense of belonging.
\end{abstract}

\section{Subject Areas}

Culture

\section{Keywords}

Tiger Totem, Yi Culture, Totem Worship

\section{Introduction}

\subsection{Research Purpose}

There are various totems in the Yi people's primitive totem belief. In the academic world, there are different schools of interpretation and worship of different totems. For a long time, bamboo totem and gourd totem have had a profound influence on the dominant status of tiger totem. As the most accepted, believed and worshipped totem by the ancestors of the Yi people, the tiger totem has had a profound impact on the life, spirit and culture of the Yi people [1]. Exploring the national spiritual food and culture and its significance to the nation is an important way to understand and review the living conditions and spiritual 
and cultural beliefs of the Yi people's ancestors in the long history. This paper will analyze the leading position of tiger totem from the function and source of tiger totem, hoping to provide reference for the study of national tiger totem.

\subsection{Research Background}

Yi people's worship of totem is the Yi studies in the field of indispensable important aspect. Taking the study of Yi nationality of Yi people's worship of totem, from a view of tiger Yi a variety of totem culture, research shows that every aspect of Yi social life is also in full swing and view of totems grasps to legends. The records of the History of China support the pattern of engraving, so far in some areas; there is still totem worship other than the tiger totem.

\section{Totem Worship of the Yi People}

\subsection{Arguments of Diverse Totem Worship of Yi People}

Diversity of ecological environment and diversity of ethnic communities have created diversity of totem worship, among many totem worship Yi people most accepted and loved the tiger totem worship, gourd totem worship, bamboo totem worship these three categories [2].

Wang Lizhu's book on The Worship of the Ancestors of the Yi Nationality studies the worship of the totem ancestor of the Yi nationality. Yi Totem and the Origin of Religion by He Yaohua studies the existence of a large number of totem relics in Yi society before liberation. Ma Xueliang's Yi Zhu and Totem studies the totem system in the ancient clan lineage and the modern clan name. The twelve kinds of descendants of the Snow nationality recorded in the Old Yi Classic of Liangshan, "The Twelve Branches of Xue Zi", are the ancient totems of the Yi nationality.

\subsection{Struggle of the Totem of the Yi People}

\subsubsection{Tiger Totem Argument}

There are dozens of Yi clade, and the most populous clade is the clade that calls itself "Luo Luo". The Yi people in Yunnan, Sichuan and Guizhou all believe that they are the descendants of the tiger people, and they call themselves "Luo Luo", which in Yi language is the title of tiger "Luo" [3]. In the name of tiger language places in sichuan and yunnan qian Yi Lin area, it is worth noting that these Yis place names are either neutral "lo", "la", "lu", "lu" and "pull", either the female "la mo", "la mother", "rama", "strong technical strength" and "pull" little male named after the "a", This, on the other hand, shows that the Yi's worship of the tiger originated from the matriarchal society [4].

\subsubsection{Bamboo Totem Argument}

The bamboo worship of minorities in southwest China covers the cultural elements of nature worship, totem worship and ancestor worship, forming a unique "southwest bamboo worship cultural circle". And the records about bamboo worship in Yi nationality's historical books are the most abundant [5]. The 
bamboo king myth in Yi culture-historical books of Yunguichuan in "Yi Bo Discussing Pu", "Yi Na Sad Song" and "Inviting the Dead" and the bamboo king myth in "Huayang Guozhi" confirm each other and become the main source of bamboo worship of southwest minority nationalities in Chinese historical books. In terms of customs and beliefs, the Yi people in Sichuan, Yunnan, Guizhou and Guizhou provinces can't make ancestral lingpai without "bamboo". The Yi people believe that they originated from bamboo and will change into bamboo again after death.

\subsubsection{Calabash Totem Argument}

It is not accidental that the ancestors of the Yi nationality took calabash as a totem well, but it had factors of food, witchcraft and myth. Calabash worship widely exists in yunnan, Sichuan, Guizhou, Guangxi Yi ethnic communities [6]. The calabash worship of Yi nationality originated from matriarchal society, which is manifested as the worship of the mother body because it looks like the belly of a pregnant woman. As gourd worship of the explicit representation of Yi's culture, can say is a sign of a different level of productivity development, reflects the development of social relations and the abundance of human consciousness, is a natural a nation spirit worship or religious legacy, contain the aesthetic taste, aesthetic ideal and aesthetic pursuit, is the national character, psychological refraction.

\section{Analysis of the Tiger Totem}

\subsection{Origin of the Tiger Totem}

The tiger is the totem of the Yi nationality. The origin of the tiger totem can be divided into three aspects. The first is the source of myth. In the folk epic Mage of the Yi people, there is a record about the creation of the world by tigers: "The head of the tiger is the head of the sky/the tail of the tiger is the tail of the sky/the ear of the tiger is the ear of the sky/the left eye is the sun/the right eye is the moon....". The second is the nature of the tiger. The Yi people regard the tiger as their tribal totem and their ancestors. They value the image of totem, hoping that their people are as strong, brave and fierce as tigers, and hope that their tribes are indestructible and have strong survival competitiveness. The third is religious belief. Yi people's religious belief is still in the stage of primitive religion, and their understanding of totem worship is still the same as that of ancient times, and they believe that they are the embodiment of the tiger.

\subsection{Embodiment of the Tiger Totem}

\subsubsection{Application in Ephemeris Culture}

The use of the tiger totem is reflected in the ephemeris culture of the Yi people, the selection of auspicious days and the traditional zodiac algorithm. In the solar calendar of the Yi nationality in October, there are 16 tiger star, 9 tiger star, 8 tiger star and so on. In Ailao Mountain area of Yunnan Province, the Yi people led by the tiger "Twelve beasts" and Yi language "Mother Tiger calendar tablet". 
It can be said that the Yi culture with the tiger as its ancestor is the embodiment of the ancient Qiang Rong Fuxi culture, namely the tiger totem culture, which is a kind of totem worship. Unlike the Han Chinese zodiac with the rat in the first place, the Yi zodiac with the tiger is in the first place. Yi people use the tiger as the top of the calendar, for the use of year, month, day and time. When holding weddings, funerals, sacrifices and other important activities, Liangshan Yi people choose "tiger day as the best auspicious day".

\subsubsection{In Funerals}

There are traces of tiger totem worship in the traditional mourning customs of Yi nationality, which is closely related to the origin of Yi nationality culture. In the section of Meigu about "releasing the dead tiger and creating the universe": "There are tigers on the mountains, and tigers are the fiercest things in the world. Lead the tiger! Coax the tiger! With the tiger's backbone support tianxin, with the tiger's foot rod bone support four sides." To dig deeper into its origins, according to the Yi nationality's custom of burying the tomb of the sky, "wearing tiger skin" and burning the corpse before burial, all things in heaven and earth originated from the tiger, and now everything is changed by the tiger, so as to show that they are the descendants of the tiger, was a tiger in life, and returned to the ancestral tiger culture after death.

\subsubsection{Representation in the Name}

Many Yi tiger totem culture is about place names, names, etc from the tiger and the designation of hills in Guizhou Weining map furnace has the place name "Luo Luo", this is the local Yi who, in the long-term production and life, the han and other ethnic minorities is "Luo" is defined as Yi lived, manifested the impression is a kind of culture. In addition, there is also the big grave Liangzi in Yancang Town, Weining County, Guizhou province, which is called "Zumu Wuqu" (meaning "king's grave") by the local Yi people. In this cemetery, the archaeological discovery of Shi hu is now in the Cultural Center of Weining County. And in many Yi villages, there are stone tigers, whose role is to drive away evil and keep the meaning of integrity.

\section{Functions of the Tiger Totem}

\subsection{Function of National Identity}

In the ancient Yi society with backward productive forces, the ancestors of the Yi people had their own totem worship for a long time [7]. When protecting or sacrificing totem, it was established as a folk worship belief of the Yi people. From their production and living reality, seeking a fit with their development needs, the symbol of life from the perspective of the world or life to know and explain the origin and development of this nation, the nation will set up a development system and cultural system, and change with the development of our nation, for national development, the cultural inheritance. In this process, the people who were on the edge of other totems came out from the fog of totems smoothly, de- 
fined their own national totem worship and formed their own national culture, which continued and developed continuously. Tiger totem worship of the Yi people is no longer simple totem worship, but the embodiment of national culture, is the solace of a national spirit, which is the irreplaceable precious cultural and spiritual wealth of Yi people.

\subsection{Cultural and Educational Functions}

Totem worship is a symbol of ethnic culture. At present, it can be understood as a specific embodiment of a nation's "values" or in the totem worship of many nations in the world. In Yi culture, tiger totem worship is closely connected to the spirit of the members of the clan ties, make the group members of the tribe together, let group members recognize that "what is it that they unite together, by what make oneself and the community as a unified", so "totem worship is a kind of joint principle".

\subsection{Life Production Application Function}

In the Yi culture, there are many "tools" of production and life with the cultural symbol of tiger totem. In the traditional costumes of the Yi people, the cultural symbol of the tiger totem is also reflected. In the Chuxiong Yi Autonomous Prefecture of Central Yunnan Province, the traditional costumes of the Yi nationality are inseparable from the cultural symbol of the tiger totem from the birth to the growth of the children. This is not only about the application of the tiger totem in production and life, but also a reflection of the cultural and educational function. In the period of primitive social development, the Yi people, like other nationalities, would place their national origin and the development of their strength on natural things or certain natural phenomena in order to seek peace of mind and reproduction of the nation. The original force comes from human beings themselves, and it is also the strength of human beings' sustenance and belief in totems in nature.

\section{Conclusion}

As a symbol of strength and majesty, the tiger was revered by the ancestors of the Yi people as a primitive totem and a symbol of auspiciousness and happiness. From the myth and legend of the tiger giving birth to all things in the universe to the myth of the alternation between human and tiger, from the totem belief worship to ancestor worship, from the tiger calendar, tiger star, tiger painting, tiger embroidery, clothing and craft, there is everywhere tiger culture, which can be described as rich and colorful, countless characteristics of tiger culture. Tiger totem is also a carrier of spiritual sustenance and religious belief of the Yi people in the long history. It is also an important link to strengthen the emotion and closeness between the nationalities, tribes and clans. The culture, connotation and spiritual sustenance endowed by the tiger totem cannot be lost or replaced by the nation. In the process of national survival and reproduction, 
the nation will develop into a strong nation with its own national beliefs, national roots and national culture in a positive and upward manner.

\section{Conflicts of Interest}

The author declares no conflicts of interest.

\section{References}

[1] Ma, L.Y. (2020) Splitting and Changing Forms of Totem of Yi Nationality. Institute of Minority Religions, Beijing.

[2] Li, X.N. (2019) Analysis of the Cultural Logic behind the Totem Worship of Yi Nationality Tiger. Journal of PLA Art Academy, 32, 48-52.

[3] Chen, Z.S. (2017) Review and Rethinking on Totem Worship of Yi Nationality. National Religion and Western Frontier Research, 54, 34-39.

[4] Chen, G. (2020) Academic Conception and Real Life-The Current Situation and Deepening of the Struggle for Totem of Yi Nationality. Observation of Fine Arts, 43, 57-61.

[5] Qu, X.Q. (1992) The Bamboo Totem Worship of the Ancestors of the Southwest Ethnic Groups and Its Remains. Guizhou Literature and History Series, 51, 23-29.

[6] Chen, F.-H. (2009) On the Generation of the Yi People's Gourd Totem in the Early Period. Journal of PLA Art Academy, 21, 62-64.

[7] Cai, W. (2019) Study on the Totem of Yi Nationality Tiger from the Perspective of Religious Anthropology. School of Law and Law, Guizhou University of Finance and Economics, Guangzhou. 